\title{
Assessing the Influence of Parenting Styles and Gender on Career Choice among Undergraduate Students of Methodist University College Ghana
}

\author{
Peter Worlanyo Abomah \\ Department of Social Sciences, Methodist University College, Ghana
}

\begin{abstract}
The study assessed the parenting style and gender influence on the career choice of undergraduate students of a private tertiary institution in Accra Ghana. A Cluster sampling technique was employed to collect data. A sample size of 160 respondents, made up of 62 males and 98 females of the Methodist University College, participated in this study. Standardised questionnaires were used to collect data from respondents. Descriptive statistics and multiple regression techniques in SPSS were applied to test the hypotheses of the study. The findings indicated that parenting styles reliably predict career choices among both male and female undergraduates. Democratic and strict parenting styles had a positive and significant influence on career choice. Gender difference had a negative influence on career choice. Permissive parenting style, uninvolved-neglectful parenting style, educational level of students, and age of students were statistically insignificant on career choice of students.
\end{abstract}

Keywords: Parenting styles and career choice, Gender, Authoritarian, Permissive and authoritative parenting.

\section{Introduction}

Career choice is significant and conceivably a very difficult process that one must undertake at some time in life. Two factors that influence the career decision-making of students are parenting style and gender. Parenting styles can affect the decision-making process of the student and may affect the career ambitions of the student through parental communications, participation in talent identification and development, career experiences, and objectives.

An Individual may graduate and not even find ready employment fit for the course they studied or career path they chose because of the interference from their parents. This can become very exasperating for most students. This may have an emotional impact on the child in a positive way on the basis that he or she can handle it, but undesirably when the child has other things in mind, the outcome of this is that the child will not attention to the parents' needs and so will not adjust positively towards the career. Parenting styles that see less of parents influencing the decision making of the child may result in most undergraduates making wrong or inappropriate decisions on their career decisions due to lack of information. Ignorance, peer influence, wrong modelling due to status attached to certain careers without enough guidance and career counselling on the side of the parents affect career decision making [1]. Again, the role gender plays in one's life and career choice are very vital world-wide and most especially in Africa. For example, women are not presented much in engineering and technical education in some developing countries like Ghana due to unconscious influences in the home from parental/family opinions, cultural and social norms.

According to [2] girls are not encouraged to pursue engineering and technical courses. General thought is that these are too difficult, and therefore suitably only for men [3]. In the face of the ever-changing world of work, career 
choice has become a multi-faceted challenge among student's world of work. Moreover, many students choose careers which later they wish to change, a decision that is so expensive in the future as they have failed to find their place in life [4]. Some students select careers that match their parents' but fail to match their parents' productivity level. The parents often desire what they deem best for their children, yet that does not provide the desired career match.

Nevertheless, an individual going through late adolescence would be developing their individuality and slowly removing their parent's constrictions as they form their own identity into the larger world. The student would make career choice decisions based on their own interest research and occupational goals with restricted influence from others. Even when young adults leave home, the likelihood of their family affecting their careermaking decision and choice of a life partner is very high. Therefore, to ensure great efficiency and productivity of the students in the work field, and to facilitate vocational counselling, it is necessary to study the influence of parenting approaches on career choice of undergraduates, provide students with proper guidelines for right decision making and choices to exploit their skills and competence. Unfortunately, it appeared not much study has been conducted on parenting style and gender on career choice in private tertiary institutions in Ghana hence their focus. The aim is to assess the parenting style and gender influence on the career choice of undergraduate students at private Universities in Ghana. The objective of the research is to determine permissive and uninvolved-neglectful parenting styles on the career choice of undergraduate students. Determine authoritative and authoritarian parenting approaches on career choice of undergraduate students. Examine if gender differences influence the career decisions of undergraduate students. Examine the educational level of parents on career choices of undergraduate students. Determine if the age of students influences career decision-making. The hypotheses are permissive parenting style, uninvolved-neglectful parenting style, authoritative parenting style, Authoritarian parenting style, gender difference, educational level of students, and age of students does not have a significant influence on career decision making.

The findings will be beneficial to students as it will enable them to make informed career choices based on their aspirations, provide insights into the parents' role in the career choices their children make. Universities will initiate programmes that will sensitize and educate parents on the influence they have on career issues affecting their children. The findings will be useful to the Government, particularly the Ministry of Education and other relevant bodies, to frame policy directions that will focus on parents' involvement in their children's career decisions.

\section{Literature Review}

The theory of [5] seeks to classify individuals according to the type of work they are most involved in and then classify occupations to assess their congruence under the same scheme. In the words of Holland, people appear to behave on their dominant interests and pursue professions where they can demonstrate their interests [5]. The real scheme of [5] was based on a six-point hexagon concentrating on six styles of individuals and occupations that are practical, investigative, creative, social, enterprising, and traditional. Gottfredson's theory of career growth is a more recent contribution in contrast to well-known career development models such as Super and Holland's theories. According to [6] posited that job selection is a process that involves a high degree of cognitive skills. The capacity of a child to combine and pull together complicated work-related knowledge is a function of both the development of chronological age and general intelligence. 
Gottfredson [6] expanded on the complex interplay between genetic composition and the environment in recent revisions of the theory. This led [6] to establish a system for career guidance interventions. It was aimed at reducing the threat and improving growth, promoting positive adaptation to cognitive development, self-creation, circumscription, and compromise. The model included plans and tools for counsellors which could be used to refine the following. (a) Learning and dynamic use of occupational knowledge. (b) Knowledge and experiences that give children and adolescents space to consider their personal characteristics associated with their professions. (c) Self-insight to build and hypothesize a rational and feasible potential career direction. (d) Ultimately, self-investment wisdom in raising the chances of effectively adopting desired career choices. These systematic techniques are applicable to different cultural environments where there are resources in school settings for career interventions.

Social Cognitive Career Theory by [7] is based on the theory of "self-efficacy" by [8], which posited a relationship between people and their environment that was mutually influential. The style of parenting refers to the way parents elect to raise their children, and such types are very significant factors in the socio-emotional growth and development of children. The research of [9] study showed that two fundamental elements lead to good parenting: parental responsiveness and challenging parenting. Baumrind's research: established Three initial parenting types: authoritative parenting, authoritarian parenting, and permissive parenting [9].

Career has become an intrinsic factor in global economic developments. However, a decision on the choice of a particular career suit to one's interests is complex and poorly understood [10].

In a report, [11] revealed that Nigerian male students viewed parental influence as a factor that had an effect on their choice of a secretarial profession that is more inclined to female students. Similarly, [12] found that Indian fathers were found to be the most important influence on Indian boys' and girls' career choices in management. Nevertheless, a study conducted by [13] on "Influence of Education on Career Choice: A Study on Sylhet City Bangladesh" revealed that there are no substantial variations in the use of knowledge and skills in their field of work among respondents of different educational levels.

\section{Methods}

This study employed a descriptive survey study design. Descriptive design permits the researcher to select relevant variables to analyze the existing relationship between events or conditions that exist or have occurred [14]. The target population for this study consisted of all levels 100, level 200, level 300, and level 400 students at Methodist University College, Ghana. Cluster sampling was employed. Subsequently, a simple random sample is taken from these clusters, all of which are used in the final sample. A total of 160 students comprising 62 males and 98 females were sampled for the study. An online data collection technique through Google forms was used. The questionnaire link was sent across platforms from levels 100 to 400 , and responses were received from respondents accordingly. The study employed adapted questionnaires from the Parenting Style Inventory-II (PSI-II) by [15] for the data collection. The questionnaire was in three sections namely, section A, section B, and section C. Section A drew biographical data of the respondents. Section B dealt with items on parenting styles which consist of permissive style, authoritative style, authoritarian parenting style, and uninvolved-neglectful parenting style. There were 6 items under each parenting style. For statistical purposes, numerical values were assigned to respective responses as follows: Strongly Disagree 1, Disagree 2, Neutral 3, Agree 4 and Strongly Agree 5. Section $\mathrm{C}$ dealt with career choice. This section 
had 11 items to be checked by respondents with the same numerical values assigned to the aforementioned.

Due to the COVID-19 pandemic, the researcher used an online data collection technique through google forms. The link to the forms was shared with the various course representatives, who in turn shared it on their various WhatsApp group pages for completion by the respondents. Data Analysis: The data obtained was analysed. It involved classification and tabulation of data collected so that they are amenable to analysis. Statistical package for social sciences (SPSS) was used. All the raw data was therefore converted into information to permit interpretation and further analysis made using both descriptive statistics to analyse the profile of respondents; the Cronbach's alpha was used to test the reliability of the constructs for the variables, and regression analyses were used to determine the influence of the various parenting styles on the career choices of undergraduate males and females. Model for Regression Analysis: For regression analysis, independent variables for the study include Gender, Educational level (EL), Age (A), Permissive styles (PS), Uninvolved-Neglectful parenting styles (UPS), Authoritative parenting styles (AS), and Authoritarian parenting styles (APS). Career choice (CC) was the dependent variable. A multiple linear regression model was used to predict organization performance using the seven independent variables in the study: In addition, the $\beta$ coefficients for each independent variable generated from the model was subjected to a $\mathrm{z}$-test, in order to test each of the hypotheses under study. The regression model used to test is shown below:

$$
\begin{aligned}
& Y=\beta_{0}+\beta_{1} X 1_{i t}+\beta_{2} X 2_{i t}+\beta_{3} X 3_{i t}+ \\
& \beta_{4} X 4_{i t}+\beta_{5} X 5_{i t}+\beta_{6} X 6_{i t}+\beta_{7} X 7+\epsilon_{i t}
\end{aligned}
$$

Where:

$\begin{array}{lll}\beta_{0} & : & \text { Constant } \\ \beta_{1} \rightarrow \beta_{7} & : & \text { Partial regression coefficient } \\ \mathrm{X} 1 & : & \text { Gender Difference (GD) } \\ \mathrm{X} 2 & : & \text { Educational Level (EL) } \\ \mathrm{X} 3 & : & \text { Age (A) } \\ \mathrm{X} 4 & : & \text { Permissive styles } \\ \mathrm{X} 5 & : & \text { Authoritative Parenting styles } \\ & & \text { (AS) } \\ \mathrm{X} 6 & : & \text { Authoritarian Parenting styles } \\ & & \text { (APS) } \\ \mathrm{X} 7 & : & \text { Uninvolved-neglectful } \\ & & \text { parenting styles (UPS) } \\ \in & : & \text { Error term }\end{array}$

The research was followed in consonant with the guidelines of research Ethics in MUCG.

\section{Analysis}

Figure 1 presents the distribution of respondents by gender. It indicates that out of the 160 respondents, $61 \%$ ( $n=98)$ were females, and $39 \%(n=62)$ were males.

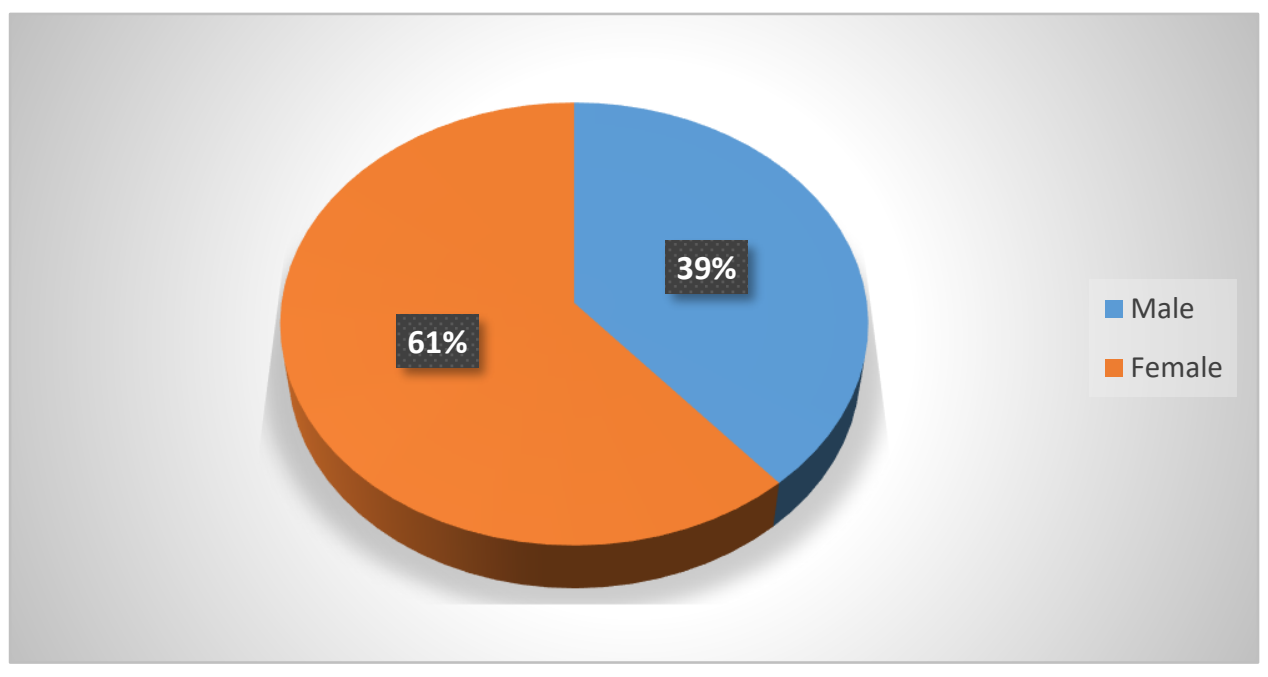

Figure 1. Distribution of Respondents by Gender 


\section{Level of Education}

Figure 4.2 gives a clear indication of the level of the respondents used for the study. The blue colour represents the level of the respondents, and the red colour is the percentage of the number of respondents used for the study. From figure $4.2,6.9 \%$ (that is 11 respondents) were level 100 students, $14.4 \%$ (23 of the respondents) were level 200. 24.4\% (39 respondents of the study) were level 300 students, and finally, $55.4 \%$ (87 of the respondents) were level 400 students. From the information gathered, it is established that most of the respondents were level 400 students.

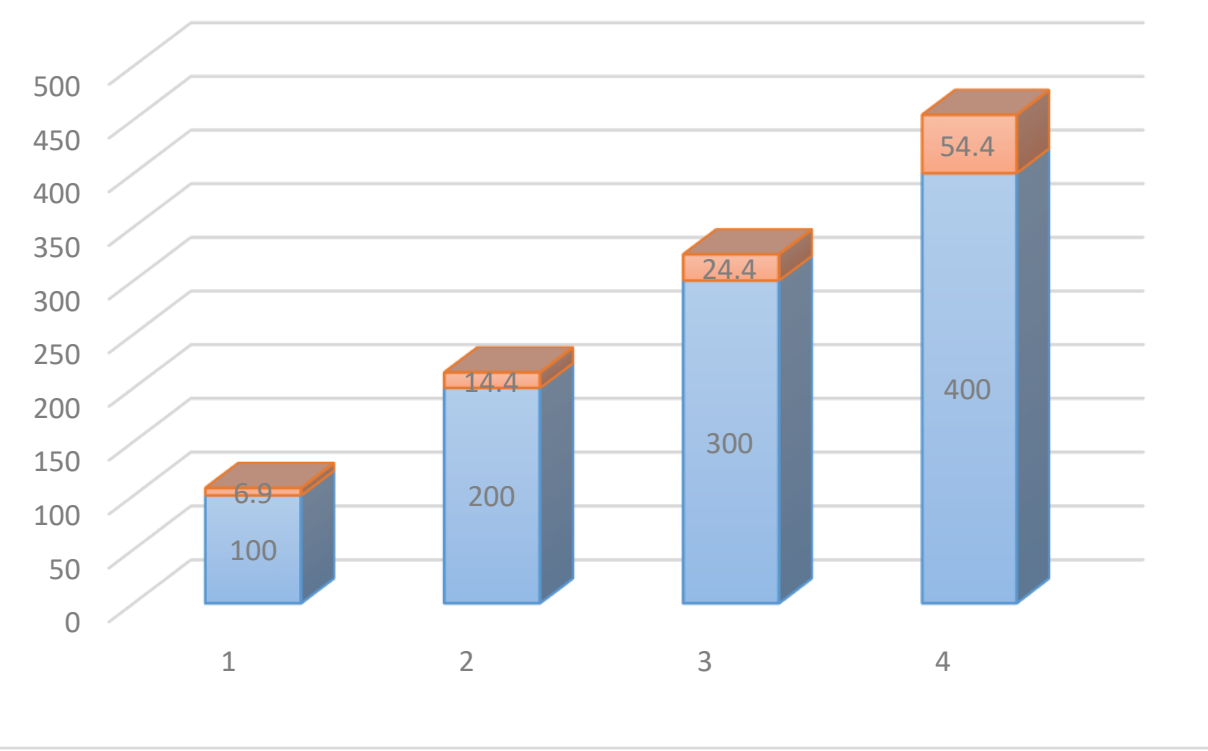

Figure 2. Respondents Educational Level

Figure 3 presents the distribution of females were aged 18 and above. Figure 4 respondents by age. It shows that all 160 Respondents Programme of Study.

respondents comprising 62 males and 98

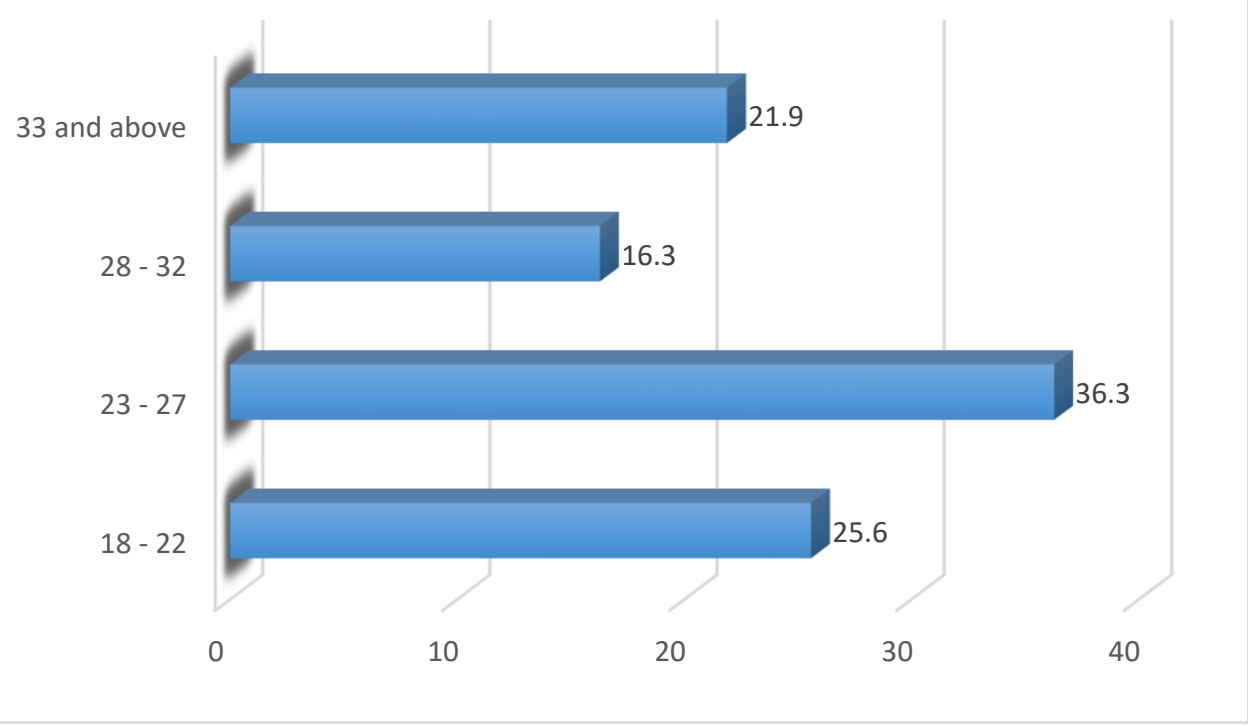

Figure 3. Age of Respondents 


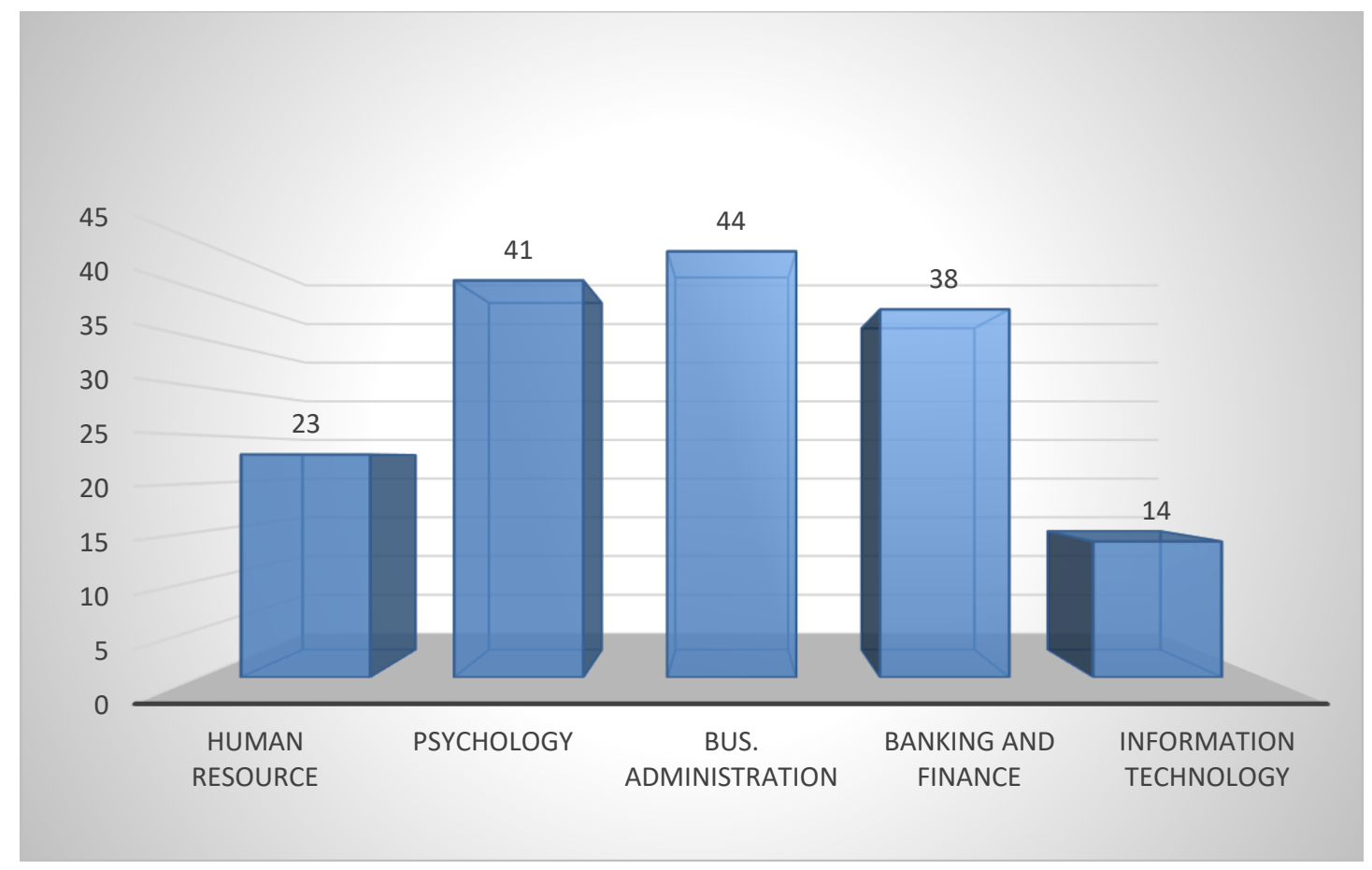

Figure 4. Respondents Programme Offered

\section{Reliability Tests}

The Cronbach's alpha was used to determine the reliability of the constructs for the factors constituting parenting styles and career choice.
According to [16] $\alpha<0.5$ is unacceptable; $0.5=$ $\alpha<0.6$ is poor; $0.6=\alpha<0.7$ is acceptable; 0.7 $=\alpha<0.9$ is good; and $\alpha=0.9$ is excellent.

Table 1. Reliability of Parental Style and Career Choice Factors

\begin{tabular}{|l|l|l|l|}
\hline Variable & $\begin{array}{l}\text { Number of } \\
\text { factors }\end{array}$ & $\begin{array}{l}\text { Cronbach's } \\
\text { Alpha }\end{array}$ & Implication \\
\hline Independent & 6 & $0.668(\sim 0.7)$ & Acceptable \\
\hline Permissive Parental Style & 6 & $0.698(\sim 0.7)$ & Acceptable \\
\hline Authoritative Parental Style & 6 & $0.774(\sim 0.8)$ & Good \\
\hline Authoritarian Parental Style & 6 & $0.771(\sim 0.8)$ & Good \\
\hline Uninvolving Parental Style & 6 & \multicolumn{5}{|l}{} \\
\hline Dependent & 11 & $0.681(\sim 0.7)$ & Acceptable \\
\hline Career Choice
\end{tabular}

Source: Survey Data Analysis (2020)

In Table 1; there were 6 factors for Permissive Parenting Style with an alpha of 0.7 (acceptable); 6 factors for Authoritative with an alpha of 0.7 (Acceptable); 6 factors for Authoritarian with an alpha of 0.8 (Good); and 6 factors for Uninvolving Parenting Style with an alpha of 0.8 (Good). Career Choice had 11 factors with an alpha of 0.7 (Acceptable). The variables can therefore be safely used to determine the effect of parenting styles on the career choice of male and female undergraduates. Descriptive statistics include measures of means and standard deviation. The table presents descriptive statistics of the variables used in the instrument. Methodist University College Ghana students were asked to rate various items using a five-point Likert scale ranging from Strongly Disagree - 1, Disagree - 2, Natural - 3, Agree - 4, and Strongly Agree -5 . The items measured were 
for five underlying variable constructs, which comprise one dependent variable (Career Choice) and the other four independent variables constructs (Permissive parenting style, Authoritative Style, Authoritarian Parenting Style, and Uninvolving Parenting Style.

\section{Regression Analysis}

Table 2 indicates the regression model summary. The R-square value measured how well the regression model explained the actual variation in the independent variables. The table indicated that R-square is equal to 0.146 . This implied that the predictors (Uninvolvedneglectful Parenting Style, Authoritarian Parenting Style, Age, Educational Level, Gender, Permissive Style, and Authoritative Style) jointly influenced about $14.6 \%$ of the changes that occurred in the dependent variable "Career Choice". The adjusted R-square is called the coefficient of determination. It informed how Career Choice varied with Uninvolving Parenting Style, Authoritarian Parenting Style, Age, Educational Level, Gender, Permissive Style, and Authoritative Style. The value of the adjusted $\mathrm{R}$ square is 0.107 . This implied that there was about $10.7 \%$ assurance that the independent variables "Uninvolved-neglectful Parenting Style, Authoritarian Parenting Style, Permissive Parenting Style, and Authoritative Parenting Style, Gender, Educational Level and Age" reliably predict the dependent variable "career choice".

Table 2. Regression Model Summary

\begin{tabular}{|l|l|l|l|l|}
\hline Model & $\mathbf{R}$ & R Square & Adjusted R Square & Std. Error of the Estimate \\
\cline { 2 - 5 } & $.382 \mathrm{a}$ & .146 & .107 & 5.659 \\
\hline
\end{tabular}

Source: Survey Data, 2020

Table 3 presents the analysis of the variance (ANOVA) table showing results for the F-test for the statistical implication of the model above. It considered whether the regression sum of the square is statistically significant, considering the number of variables needed to achieve it. At a 95\% confidence level, "i.e., 5\% level of significance", the model above is statistically significant and therefore indicated that we are more than $95 \%$ confident our model, which assessed the parenting style and gender influence on career choice of undergraduate students at Methodist University College of Ghana are predictably accurate. This implies that the independent variables in the model reliably predict the dependent variable.

Table 3. ANOVA, Regression Significance

\begin{tabular}{|l|l|l|l|l|l|}
\hline Model & Sum of Squares & Df & Mean Square & F & Sig. \\
\hline Regression & 831.259 & 7 & 118.751 & 3.709 & $.001 \mathrm{~b}$ \\
\cline { 1 - 4 } Residual & 4867.235 & 152 & 32.021 & & \\
\cline { 1 - 4 } Total & 5698.494 & 159 & & & \\
\hline
\end{tabular}

Source: Survey Data Analysis, 2020

Table 3 indicates the significance for $\mathrm{p}$ value for each independent variable represented the variable in predicting the independent variable. For the first independent variable "gender differences" was statistically significant $(\mathrm{t}=$ 2.259, Beta $=-0.172 ; p=0.025)$. This suggested that gender predict of career choice undergraduate students. Independent variable "educational level" was $(\mathrm{t}=1.909$, Beta $=$ $0.145 ; \mathrm{p}=0.058)$. This suggested educational level was predictor of the career choice of undergraduate students. For the third independent variable "age" was $(\mathrm{t}=-0.759$, Beta $=-0.059 ; \mathrm{p}=0.449)$. This suggested age was not predictor of career choice of undergraduate students. For the fourth 
independent variable "permissive style" was $(\mathrm{t}$ $=-1.013$, Beta $=-0.083 ; \mathrm{p}=0.313)$. This suggested permissive style was not predictor of career choice of undergraduate students. For the fifth independent variable "authoritative style" was $(\mathrm{t}=2.589$, Beta $=0.215 ; \mathrm{p}=0.011)$. This suggested authoritative style was a predictor of career choice of undergraduate students. For the sixth independent variable "authoritarian parenting style" was statistically significant $(\mathrm{t}=$ 2.924, Beta $=0.229 ; \mathrm{p}=0.004)$. This suggested authoritarian parenting style was a predictor of the career choice of undergraduate students. For the seventh independent variable "uninvolvedneglectful parenting style" $(\mathrm{t}=0.338$, Beta $=$ $0.026 ; p=0.736)$. This suggested uninvolvedneglectful parenting style was not a predictor of career choice of undergraduate students.

Table 4. Regression Coefficients of Standard Regression Model

\begin{tabular}{|l|l|l|l|l|l|}
\hline \multirow{2}{*}{ Model } & \multicolumn{2}{|l|}{$\begin{array}{l}\text { Unstandardized } \\
\text { Coefficients }\end{array}$} & \multicolumn{2}{l|}{$\begin{array}{l}\text { Standardized } \\
\text { Coefficients }\end{array}$} & T \\
\cline { 2 - 6 } & B & Std. Error & Beta & & \\
\hline Constant) & 29.888 & 4.053 & & 7.374 & .000 \\
\hline Gender Difference & -2.110 & .934 & -.172 & -2.259 & .025 \\
\hline Educational Level & .912 & .478 & .145 & 1.909 & .058 \\
\hline Age & -.325 & .428 & -.059 & -.759 & .449 \\
\hline Permissive Style & -.118 & .116 & -.083 & -1.013 & .313 \\
\hline Authoritative Style & .293 & .113 & .215 & 2.589 & .011 \\
\hline Authoritarian Parenting Style & .271 & .093 & .229 & 2.924 & .004 \\
\hline Uninvolving Parenting Style & .031 & .091 & .026 & .338 & .736 \\
\hline
\end{tabular}

Source: Survey Data Analysis, 2020

Table 5. Summary of the Hypothesis

\begin{tabular}{|l|l|l|l|}
\hline Hypothesis & Relationship & P Values & Findings \\
\hline H1 & PS $\rightarrow$ CC & .313 & Not significant \\
\hline H2 & UPS $\rightarrow$ CC & .736 & Not significant \\
\hline H3 & AS $\rightarrow$ CC) & .011 & Significant \\
\hline H4 & APS $\rightarrow$ CC & .004 & Significant \\
\hline H5 & GD $\rightarrow$ CC & .025 & Significant \\
\hline H6 & EL $\rightarrow$ CC & .058 & Not significant \\
\hline H7 & A $\rightarrow$ CC & .449 & Not significant \\
\hline
\end{tabular}

Source: Survey Data Analysis, 2020

In Table 5, where PS is Permissive Styles, UPS is Uninvolved parenting styles, AS is Authoritative parenting styles, APS is Authoritarian parenting styles, GD is Gender, EL is Educational Level, $\mathrm{A}$ is Age and $\mathrm{CC}$ is Career Choice. The impact of permissive and uninvolved-neglectful parenting styles on the career choice of undergraduate students. Permissive Parenting Style (PS) has an influence on the career choice (CC) of undergraduate students.

\section{Discussion}

Permissive parents tend to be less demanding. These parents seldom correct their children. Permissive parenting style had a negative relation toward career choice. Permissive parents are not demanding and have few expectations of their children. Permissive parents do not set rules and regulations for their children's behaviour [8]. Thus, the reason why it was statistically insignificant. That is, a change in permissive parenting style will not 
bring about a decrease in the career choice of MUCG students.

According to [17], "there is a relationship between parenting styles and creativity and the predictability of creativity by parental approaches". No relationship was found between permissive parenting style and creativity. Uninvolved-neglectful parenting style has an influence on the career choice of undergraduate students. Uninvolved-neglectful parenting style had a positive relation towards career choice, but there was no significant influence on career choice. Parents may provide basic needs in more extreme forms of neglect. This could probably be so because parents may feel too exhausted, overworked, or preoccupied to be closely involved in their wards' lives.

The findings [18] revealed that the uninvolved parents are indifferent and are sometimes referred to as neglectful. The study of [19] revealed neglectful parents might look for support and guidance, and these children often end up becoming parents to their parents. [1] supports the findings. In their study, it was revealed that parents might provide for the child's basic needs in more extreme forms of neglect. Authoritative parenting style has an influence on the career choice of undergraduate students. The authoritative parenting style was positive and had an influence on the career choice of undergraduate students in MUCG. This implies that a unit change in the authoritative parenting style will enforce students to have a good career choice. The result support [8] submits that these parents usually observe and impart clear principles for their children's conduct. They are assertive but not invasive and restrictive. Their corrective methods are supportive rather than punitive. The findings of [20] add to this assertion. In his findings, he submits that an authoritative parenting style, "a demanding and responsive child-rearing style which includes a high level of parental involvement, high expectations, and standards, adequate support, guidance, and encouragement, was found to be associated with better career choices as it balances clear, high expectations with emotional support and recognition of an adolescent's autonomy. This implies that as long as parents exhibit this kind of parenting style at home, it will encourage and build the confidence of their children and make them focus on the right career that will never undermine their potentials or abilities. Authoritarian parenting style has a significant influence on the career decision of undergraduate students at Methodist University College, Ghana.

The findings revealed that authoritarian parenting had a positive relationship with the student's career choice and was statistically significant. They follow their parents' rules to avoid incurring their displeasure. Even though this style had a positive relationship with career choice, it could probably be as a result of the do as I say rules. This could influence the children as they often do not offer or study the programmes or courses because they have any interest in them. Rather, they choose them to fulfill their parents' desires. This implies that a unit change in the authoritarian parenting style will increase the career choice of undergraduate students in MUCG. It is further supported by [21].

Parents who adopt an authoritarian style have very high expectations yet provide very little by way of feedback and nurturing. Children are required to go strictly by parents to set rules. If the children fail to comply with the set rules, it often comes with punitive measures. The study of [22] submits that this parenting style is detrimental to children's educational or professional outcomes; further, as noted by [4], students who are brought up in authoritarian homes often become anxious or withdrawn or suffer from self-esteem problems. The result confirms the work of [23] career development and counselling issues should be moved from theory to practice research work, providing opportunity for appreciation of career counselling. 
Gender influences the career choice of undergraduate students. Gender had a negative influence on career decision and was statistically significant. The findings support [9] that gender plays a key role in career choices. Educational level has an influence on the career choice of an undergraduate students. Findings from the study revealed that the educational level had a positive relationship with career choice but was statistically insignificant. The findings support [12] who submitted that the entrance, expectation about deliberation, and returns are the main concern for the selection of careers by educated youth. Age has an influence on the career decision-making of undergraduate students. Age had a negative influence on a career but was statistically insignificant. The finding is in line with [1] study on "Gender, identity status and career maturity of adolescents in Southwest Nigeria. In addition, [24] found out that adolescents within 15-17 years do not significantly affect the way they perceive the various worlds of work.

\section{Conclusion}

Parenting style is a climate parents raise their children. The authoritative parenting approach was positive. This means that parents who enforce this kind of parenting approach by exhibiting involvement, high expectations, and standards, adequate support, guidance, and encouragement to their wards will help them develop a sense of career choice. The authoritarian parenting style had a positive and significant relationship with career choice. This implies that it had an influence on a career decision. Gender difference had a negative influence on career decisions and was statistically significant. A unit change in gender difference will lead to a student adjusting their interest in a particular career choice. Permissive parenting style, uninvolved parenting style, educational level of student, and age of students were statistically insignificant. Parents adopt an authoritative parenting style to ensure that their undergraduate children are well-informed on a future career. Parents who adopt the authoritarian parenting style should consider varying it with other nurturing modes. Students should be encouraged and given equal opportunities in career decision-making without regard to their gender. School counsellors should consider gender issues when career choice is to be treated as this would guarantee career stability in the future. Children should be guided in their career decision-making at every stage of their life.

\section{Acknowledgement}

The contribution of Eunice Sakodie-Addo by assisting in collecting data for the study is acknowledged. The researcher acknowledges all sources cited and respondents used in the study.

\section{Conflict of Interest}

The study was limited to the private Universities in Ghana. This might narrow in coverage. The sample size was relatively small. The researcher used students under supervision to assist in data collection. The researcher's interest in the choice of the topic is due to the area vocational guidance and counselling being taught by the researcher. 


\section{References}

[1] Salami, S. (1999). Relationship Between Work Values and Vocational Interests Among High School Students in Ibadan, Nigeria. African Journal of Educational Research, 5(2), 65-74.

[2] Mlama, P. (2001). Gender Equity Programming in Higher Education. Paper Presented at The Higher Education Policy Forum.

[3] Evans, D. (2006). A paper on Long Life Goals: Antecedents in Gender Beliefs and Effects on Gender Stereotypical Career Interest. Oxford, Ohio: Miami University.

[4] Onyango, C (2016). Education Retrieved from www.education.com/reference/article/effectparenting-styles-children-behavior/.

[5] Holland, J. (1996a). Exploring Careers with A Typology: What We Have Learned and Some New Directions. American Psychologist. 51, 397- 406.

[6] Gottfredson, L. (2002). Gottfredson's Theory of Circumscription, Compromise, and Self Creation. In D. Brown; Associate (Eds), Career Choice and Development (4th ed.). San Francisco, CA: JosseyBass.

[7] Lent, R., Brown, S., \& Hackett, G. (2002). Social Cognitive Career Theory. (4th ed.). (D. \&. Associates, Ed.) San Francisco: Jossey-Bass.

[8] Bandura, A. (1997). Self-Efficacy: The Exercise of Control. New York: W.H Freeman and Company.

[9] Baumrind, D. (1966). Effects of Authoritative Parental Control on Child Behaviour. Genetic Psychology Monographs, 37(4), 887-907.

[10] Almiskry, S., Baker, R., \& Mohammed, O. (2009). Gender difference and Career Choice interest among undergraduate students: Implication for Career Choice. European Journal of Scientific Research, 26 (3), 465-469. Retrieved November 19, 2019, from http://www.eurojournals.com.ejsr.htm.

[11] Igbinedion, V. (2011). Perception and Factors that Influence Students Vocational Choice of Secretarial Studies in Tertiary Institutions in Edo State, Nigeria. European Journal of Educational Studies, 3 (2), 325-337.

[12] Agarwala, T. (2008). Factors Influencing Career choice of Management Students in India. Career Development International, 13(4), 362-376.

[13]Latif, A., Aziz, A., \& Ahmed, M. (2016). Influences of Education on Career Choice: A Study on Sylhet Cit Bangladesh, Management Studies and Economic Systems (MSES). 2(3), 211-217.

[14] Gravetter, F., \& Forzano, L. (2006). Research Methods for The Behavioural Sciences (2nd ed.). Thomson Wadsworth.

[15]Darling, N. \& Toyokawa, T. [1997]. A wscale to measure three dimensions of parenting style: demandingness, supportiveness and psychological anatomy grating. Construction and Validation of The Parenting Style Inventory II.

[16] Manerikar, V. \& Manerikar, S. [2015]. Cronbach's Alpha. A Peer Reviewed Research Journal. XIX [1],117-119. Doi;10.1007/bf02310555. [17]Turner, E., Chandler, M., \& Heffer, R. (2009). Influence of Parenting Styles, Achievement Motivation, And Self-efficacy on Academic Performance in College Students. Journal of College Student Development, 50 (3), 337-346.

[18]Patton, W., \& McMahon, M. (2006). Career Development and Systems Theory: Connecting Theory and Practice (2nd ed.). Rotterdam, The Netherlands: Sense Publishers.

[19]Kumar, A. (2007). Personal, Academic \& Career Development in Higher Education: Soaring to Success. New York, NY: Routledge.

[20] Rani, S. (2014). Impact of Parenting Styles on Career Choice of Adolescents. Journal of Education and Social Policy, 1 (1). 34-39.

[21] Cartwright, H., McNally, S., White, C., \& Verduyn, C. (2005). Parent Skill Training: An effective intervention for internalizing symptoms in younger children. Child and Adolescent Psychiatric Nursing, 7, 128-139.

[22] Owusu-Kwarteng, L. (2015). Telling a Different Story: The Effect of Parenting on the Academic and Professional Achievement of 24 British-Ghanaian Highflyers. Power and Education, 7, 289-305. doi: $10.1177 / 1757743815600292$.

[23] Brown, S., \& Lent, R. (2005). Career Development and Counselling: Putting Theory and Research to Work. Hoboken, NJ: Wiley.

[24]Joseph, F., \& Olu, A. (2017). Adolescents' Gender and Age as Correlates Career Choice Among Secondary School Students in Southwest Nigeria. Advances in Social Sciences Research Journal, 157-162. 